\title{
Development of Palang Pintu As an Edutainment in Venetie̊ van Java (Batavia)
}

\section{Jenny Sista Siregar and Sri Irtawidjajanti}

Department of Home Economics, Universitas Negeri Jakarta, Jakarta 13220, Indonesia

\section{Abstract}

In the midst of the proliferation of Betawi cultural creations, one that is considered to be an intangible cultural heritage is (Open) the Palang Pintu or otherwise known as the Palang Pintu (Doorstop/Door Cross). Palang Pintu is one of the events in the Betawi wedding ceremony. The meaning and philosophy or character of the Betawi people is reflected in the Palang Pintu. This qualitative research was produced using various sources of contemporaries in the form of staatsblad, magazines, newspapers, manuscripts, and photographs with the aim of producing data as Tijdschrift voor Nederlandsch Indie, Bijdragen Koninklijk Instituut voor Indische Taal, Land en Volkenkunde, De Indische Courant, het Dagblad, Bataviaasch Nieuwsblad,

Corresponding Author: Jenny Sista Siregar jennysistasiregar@gmail.com

Received: 11 January 2019 Accepted: 14 February 2019 Published: 25 March 2019

Publishing services provided by Knowledge E

(c) Jenny Sista Siregar and Sri Irtawidjajanti. This article is distributed under the terms of the Creative Commons

Attribution License, which permits unrestricted use and redistribution provided that the original author and source are credited.

Selection and Peer-review under the responsibility of the $3 \mathrm{rd}$ ICTVET 2018 Conference Committee.

\section{G OPEN ACCESS}

Nieuwsblad van het Noorden, Inter Ocean, Sluyters Monthly, Bintang Hindia, and Radja Timoer. Palang Pintu is an educational part of the cultural values of the Betawi people. Palang Pintu currently is no longer only held in traditional Betawi wedding ceremonies but at various other events such as circumcision or welcoming guests.

Keywords: Palang Pintu, marriage ceremony, Betawi, culture

\section{Introduction}

Batavia's writings have attracted many foreign and local researchers. But the writing of the history of Betawi culture in Batavia is very little. Many writings by other local researchers are not based on facts that reflect the reality of society in the past. In History, facts become accurate data so that historical explanations are more appropriate for seeing society and culture. The author's interest has been at the regional wedding ceremony in Indonesia. Research results from the Yogyakarta Palace and Batavia areas have been published in national or international journals. The data collected is used to explain Batavia and its culture. In this case, the author conducts research based on the reality of society in the context of how society and the government should work together to preserve Betawi culture without removing the meaning and philosophy in the culture itself in this case the tradition of the Palang Pintu. Before being known as Jakarta, Europeans in the tourism slogan to attract Europeans to the Tropical Country 
equate Batavia to Venetië van Java. This is because more European travelers are willing to come to the Tropical Country and give an impression as their own home. If Bandung is known as Parijs van Java then Europeans call Batavia as Venetië van Java. Batavia was better known as a region but as a human being the Batavia region was known as a Betawi people or Betawi tribe. The origin of the Betawi tribe is more synonymous with a multi-ethnic (Betawi, Sundanese, Javanese, Madura, Minang, Southern Sumatera, Batak, North Sulawesi, Maluku, Papuan, Acehnese, Banjar, East Nusa Tenggara, dan Balinese (1) or even multi-racial society (Chinese, Japanese, Indian, Europeans) (2). Based on the area of his residence, the Betawi tribe is more local in nature with his recognition as a Tanah Abang, Condet, Marunda and so on. In this multiethnic and or multi-race society complex, the Betawi culture influences the community to be egalitarian. In this context, the things that will be discussed are the Palang Pintu as part of the program at the Betawi wedding ceremony (3). which shows the egalitarian nature of the community and how the development of the Palang Pintu becomes part of the performance in Betawi culture. The Palang Pintu was also proposed as an intangible inheritance within UNESCO (United Nations Educational, Scientific and Cultural Organization). Since 2015, Palang Pintu has been officially registered as an intangible cultural heritage in the category of Community Customs, Rites and Celebrations (http;//kwriu.kemdikbud.go.id/ info-budaya-indonesia/warisan-budaya-takbenda-indonesia/). Whereas the Palang Pintu if seen as a whole unit is included in the Customary Society, Rite and Celebration category, namely the wedding ceremony in the Betawi Tribe, but if it is said only in the form of a Palang Pintu, the Palang Pintu is part of the performing arts or dance art. Officially the category in UNESCO's intangible cultural heritage consists of five parts: 1. Customary Culture, Rites and Celebrations, 2. Traditional Crafts and Crafts, 3. Knowledge and Habits of Knowing the Universe, 4. Performing Arts, and 5. Traditions and Oral Expression. The problem in development is that the fostering of the Palang Pintu tradition should be done in various ways such as recovery, research, workshops in the framework of cultural preservation without reducing the true meaning of the Palang Pintu programme. In the case of Gambang Kromong cultural inheritance is done by traditional methods. Children learn from parents through existing training studios. Whereas the enculturation process should be carried out by many parties such as religious institutions, schools and or other social groups (4). 


\section{Methods}

This research uses more qualitative approaches. This approach still uses theories that will be brought to the field (observation area) and then will be examined more deeply based on the phenomena in the observation area. In the area of observation it is proven to be equipped with data in the form of manuscripts, photos, staatsblad and others. This qualitative research was produced using various sources of contemporaries in the form of staatsblad, magazines, newspapers, manuscripts, and photographs with the aim of producing data as Tijdschrift voor Nederlandsch Indie, Bijdragen Koninklijk Instituut voor Indische Taal, Land en Volkenkunde, De Indische Courant, het Dagblad, Bataviaasch Nieuwsblad, Nieuwsblad van het Noorden, Inter Ocean, Sluyters Monthly, Bintang Hindia, and Radja Timoer.

\section{Results}

\subsection{The egalitarian character of the Betawi people}

The egalitarian nature of the Betawi people can be demonstrated when they receive newcomers or when they move to another area. Egalitarian in a state society is social equality in which all people in a particular community or group have the same status. Social equality to get legal rights, voice opinion, education, gathering, equal security, and the same in obligations that involve all levels of society. Egalitarian Betawi people are proven in straightforward Betawi languages, and there are no rules in them (5). Betawi language is reflected in the arts of Lenong, songs, films and poetry. While the locality of the Betawi people is reflected in their attitude towards the environmental community. The Betawi people never invited their next neighbors even though they were fellow Betawi people, and some even did not tell them where they would move. Multi race and multi ethnicity have been influenced by the VOC government (Vereenigde Oostindische Compagnie) where Jakarta or Batavia were always flooded with immigrants from various ethnicities. But this tendency can be interpreted as the awareness of the Betawi people in the formation of ethnicity is not rooted, so that their geographical memory is short as Lohanda (historian and archivist) and $\mathrm{UI}$ anthropologist Supardi Suparlan. The Betawi people call themselves based on the locality of their place of residence, for example the Kebayoran people, the Senen people, the Rawabelong people and others (6). 


\subsection{Palang Pintu}

Palang Pintu in Betawi wedding ceremonies is part of the event in the Betawi wedding. Palang Pintu introduces Pantun and Pencak Silat in their performances which are presented in traditional Betawi wedding ceremonies. The meaning in the Palang Pintu is used as a condition for men who are going to marry that Betawi men have two things, namely being able to Silat as a man who will protect his wife and children and can recite because men will become imam (leader) for their families ceremony. With his Silat, the groom is able to defeat the man who is the Palang Pintu in the bride's family. It's just that in the event, the groom was replaced by one of the men who became his representative so that the ability of his martial arts was not tested and many did not understand that there were other conditions that must be mastered by the groom, namely being able to recite.

As a custom in the Betawi community, boys in the Betawi household are taught Pencak Silat and recitation in everyday life, they will practice in their home environment. When a boy has grown up and is ready to get married, these two abilities are inherent in him. It's just that the habit has been lost, the Betawi village that has been lost has made a lot of mixed up of the diverse ethnic life of the people of DKI Jakarta. At the same time, the practice of Silat was lost in their homes. While the practice of recitation is done in accordance with the habits of parents in their homes.

In the Betawi wedding ceremony, as revealed by Abdul Chaer that there is a series of events in the form of Looking around (Ngendelengin), Playing or Silahturahmi (Visiting), Proposing, Bringing Signs of Termination (Bawa tanda Putus), Ngebakal, Piare Candidates (Piare Calon Penganten), Marriage Contract, Malam Kondangan, Ngebesan, Malam Pengantenan (bridal night), Ngintip Penganten (bridal peek), Nengokin penganten (bridal visit)(3). This series of events will be carried out by the bride of the Betawi tribe who will be married. While the Palang Pintu programme is in the series of marriage contracts, all married requirements have been fulfilled and a marriage contract will be held. The marriage ceremony began with the prospective groom starting with Maulud Nabi, reciting prayers for the salvation of all, and parading the bridegroom to the bride's house. The procession group consisted of the group leader who could also act as a rhyme in the Palang Pintu event. Accompanied by a reader of Sike (chant of the holy verses of Al Qur'an) and good at martial arts from the groom who will defeat the martial arts master at the bride's house. In the entourage the goods are in the form of cakes, clothes, crocodile bread. Another group was a coconut flower carrier, a tambourine drummer, and was sometimes equipped with Ondel-ondel. 
Sike readings show the groom is good at reciting and understanding religion. Crocodile bread is a symbol of loyalty because in philosophy the Betawi people believe that crocodiles are animals that have only one partner and are clean. Then the crocodile bread that holds the child symbolizes that the crocodile loves the child and family. Coconut flower symbolizes coconut as a versatile and useful fruit as a whole. Jago Silat symbolizes that the bride is good at self-defense and that Ondel-ondel is the symbol of the devil or the devil who disturbs humans.

The group of the groom's procession will depart followed by burning firecrackers. Likewise when arriving at the bride's house will be replied with a row of firecrackers and there is a question and accompanied by pantun in the form of where to go and want what marks the Palang Pintu event. The core of the Palang Pintu programme is the success of the Silat of the groom into the bride's house which proposes conditions in the form of reading the Sike and being able to defeat the Silat bride. If it is successful, the reading of the Sike can be echoed. Enter the groom's entourage into the bride's house to carry out the marriage contract. The marriage contract is carried out by the way the groom faces the prince and the bride in the room. After the contract process is complete, the groom is escorted by the guardian of the bride into the room. Furthermore, guests can enjoy treats in the form of uduk rice, kebuli rice or samin rice or something else. The rest of the food that is not used up is usually taken home wrapped in teak leaves or banana leaves as a blessing. After that proceed with other events such as the night of kondangan, Ngebesan, Malam Pengantenan (bridal night), Ngintip penganten (bridal peek), Nengokin penganten (bride visit).

\section{Discussion}

\subsection{Palang Pintu and UNESCO}

Palang Pintu in Betawi wedding ceremonies have been included in the official list of UNESCO (United Nations Educational, Scientific and Cultural Organization) No. 49 of 2015. There have been 594 non-material cultural works registered by the Government of Indonesia between 2013 and 2017. Unusual cultural heritage in 2013 there were 77 pieces, in 2014 there were 89 and 7 shared cultural heritage with a total of 96 pieces, in 2015 amounted to 121 pieces, in 2016 there were 150 pieces and in 2017 amounted to 150 so the total number of 594 works. UNESCO is a special United Nations Agency established in 1945. The aim of the organization is to support peace and security in promoting cooperation between countries through education, science and culture 
in order to enhance mutual respect based on justice, rule of law, human rights and essential freedoms. From 2011 to 2017, this organization has registered Indonesian cultural heritage. When compared between the number of existing regional cultures and non- cultural heritage that has entered the official list of UNESCO in Indonesia is certainly very unbalanced in that number.

In the list of non-official inheritance that has been officially registered, there are also Pantun and Pencak Silat separately. Pantun comes from the word pan which means polite while tun is bound, organized and arranged. Etymologically Malay means direction, nurturing and guiding. Pantun is a form of poetry consisting of 4 lines. The first and second row rows are called sampiran while the third and fourth rows are only in the form of the contents of the actual rhymes. The pattern of poetry is the end of the line in the form of $a-b-a-b$ whose purpose is religious education, morality and character, entertainment or a description of the Betawi environment (7). In addition, rhymes can be in the form of innuendo, ridicule or joking and as a guessing game that in language reflects the egalitarian nature of the Betawi people. But at the Palang Pintu event, pantun begins with praise to the bride and groom, the purpose of the arrival of the bridegroom, the acceptance of the bride, to the gratitude or approval.

Pencak Silat in Palang Pintu is considered as a dance art because it uses body movements as a means of delivery. On the other hand Palang Pintu is considered a martial art. Palang Pintu dance is just a flower from the contents of martial arts actually. Silat is indeed a self-defense tool but Pencak Silat dance is a show that invites Betawi youth to learn Pencak Silat as martial arts. As a folklore silat genre and Pencak Silat dance, it is inherited from generation to generation. Meanwhile in the 2017 official list, Silat Cingkrik has been included in the performing arts category. The meaning of Cingkrik is people who are jingkrik. The Silat Cingkrik Movement is sometimes considered to resemble a moving monkey when avoiding people or stealing food. Silat Cingkrik was built in the 1920s by Ki Maing. In the sense of the name Silat Cingkrik that silat is also included as a combination of Silat and martial arts.

While in the Big Indonesian Dictionary Palang (wood, iron and so on) lock the door. In the current program, Palang Pintu is no longer only used in marriage, the part that is shown as a show is Pencak Silat and eliminates parts of prayer. It depends on the request and adjusts the time normally accelerated to about 15 minutes. Government development of Betawi culture has been carried out, one of which is carried out in the Setu Babakan Cultural Heritage environment. Meanwhile, in the context of preservation, there has been a Palang Pintu performance. Palang Pintu has become an annual festival by the community organization Forkabi (Betawi Communication Forum) in Jakarta's 
anniversary celebration every June in the Kemang region, South Jakarta. This has been done 12 times until 2017. In 2018, the West Jakarta Tourism and Culture Office held a Betawi Culture Festival in the form of competitions such as Lenong, Palang Pintu, Betawi Dance and Sahibul Hikayat. At present, the Palang Pintu is more like a martial arts performance than the moral message in it. The show was made short by causing fanfare to become an interesting show. Individual performances are carried out in marriage ceremonies of people who feel they have a descendant of a Betawi identity.

Meanwhile, coaching in the chain of distribution outside Setu Babakan is not so visible and felt so that the existence of the Palang Pintu tradition cannot be predicted until when it can survive. Betawi culture itself after the Regional Regulation No. 4 of 2016 has been officially considered a regional culture. With the power of this regional regulation, it is hoped that other Betawi cultural identities outside the Palang Pintu will strengthen in the future. Aside from being a conservation effort, this regulation becomes a basic or important and strategic capital to develop Jakarta tourism. The synergy of recovery efforts, research from universities and workshops was carried out in order to develop in depth without reducing the message of educating in the Palang Pintu programme so that the preservation of the Palang Pintu tradition was successful and maximal. But such synergy has not been seen in its entirety $(8,9)$. Preservation of the Palang Pintu tradition is still in the context of a competition or performance. At present the results of the research have become a new energy beginning to be felt in Setu Babakan's cultural heritage even though in various writings it is also said that the handling in Setu Babakan's cultural heritage of socio-cultural remains to be increased even the flow of links such as dance studios, bridal makeup organizations, in other areas in DKI Jakarta is carried out in the framework of fostering Betawi culture in general or the Palang Pintu in particular.

\section{Conclusion}

With the issuance of Regional Regulation No. 4 of 2016, Palang Pintu, as one of the Betawi cultural identities must get attention with good guidance so that the existence of the Palang Pintu,is a way in preserving the Betawi culture. The community is expected to have an awareness of the importance of cultural preservation in the framework of inter-national relations. Government coaching at dance studios, professional community organizations is carried out in a comprehensive and structured manner should be done if we do not want the culture to disappear and become extinct. Culture is not considered 
merely entertainment but has Eastern teaching meaning and philosophy that can be implemented in daily life.

\section{Funding}

This work was supported by a Competitive Research Grant from Universitas Negeri Jakarta in 2018.

\section{Acknowledgment}

The authors would like to thank all their colleagues for their contribution to the research. They are also thankful to all the reviewers who gave their valuable inputs to the manuscript and helped in completing the paper. In particular, the authors would like to express their gratitude to Prof. Willem and Swanhouw Lie for helping them in the smooth completion of this research. Much of the Dutch data are provided by Prof. Willem and the data on the Chinese community in Batavia were given by Swanhouw Lie, who both lived in the Netherlands.

\section{Conflict of Interest}

The authors have no conflict of interest to declare.

\section{References}

[1] Rahadian Ranakamuksa Candiwidoro. (2017). Menuju Masyarakat Urban: Sejarah Pendatang di Kota Jakarta Pasca Kemerdekaan (1949-1970). Jurnal Pemikiran Sosiologi, Volume 4, No. 1, pp. 65.

[2] Djoko Soekiman. (2000). Kebudayaan Indis. Yogyakarta: Yayasan Bentang Budaya.

[3] Abdul Chaer. (2012). Foklor Betawi: Kebudayaan dan Kehidupan Orang Betawi. Jakarta: Masup Jakarta

[4] Marissa Renimas Harlandea. (2016). Sejarah dan Enkulturasi Musik Gambang Kromong Di Perkampungan Budaya Betawi. Jurnal Seni Musik, 5, (1), pp. 27.

[5] Mita Purbasari. (2010). Indahnya Betawi. Jurnal Humaniora, Vol. 1, No. 1, pp. 4.

[6] Heru Erwantoro. (2014). Betawi Ethnic, Historical Study. Patanjala, Vol. 6, No. 1, pp. 2. 
[7] Shelma Aisya. (2016). Struktur Teks, Konteks Pertunjukan, dan Ajaran Islam Pada Palang Pintu Pada Pernikahan Adat Betawi. Arkhais, Vol. 07, No.1, pp. 27.

[8] Ariesta Amanda. (2016). Peran Agensi Budaya dan Praktik Multikulturalisme Di Perkampungan Budaya Betawi (PBB) Setu Babakan. Jurnal Pemikiran Sosiologi, Vol. 3, No. 2, pp. 53.

[9] Yasmine Zaki Shahab. (2001). Rekacipta Tradisi Betawi: Sisi Otoritas dalam Proses Nasionalisasi Tradisi Lokal. Jurnal Antropologi Indonesia, 2, 66, pp. 55. 